\title{
Cordage, basketry and containers at the Pleistocene-Holocene boundary in southwest Europe. Evidence from Coves de Santa Maira (Valencian region, Spain)
}

\author{
J. Emili Aura Tortosa ${ }^{1}$. G Guillem Pérez-Jordà ${ }^{1,2}$ · Yolanda Carrión Marco ${ }^{1}$. Joan R. Seguí Seguí ${ }^{3}$. \\ Jesús F. Jordá Pardo ${ }^{4} \cdot$ Carles Miret i Estruch ${ }^{5} \cdot$ C. Carlos Verdasco Cebrián ${ }^{6}$
}

Received: 13 March 2019 / Accepted: 31 October 2019 / Published online: 7 November 2019

(c) The Author(s) 2019

\begin{abstract}
In this study we present evidence of braided plant fibres and basketry imprints on clay recovered from Coves de Santa Maira, a Palaeolithic-Mesolithic cave site located in the Mediterranean region of Spain. The anatomical features of these organic fibre remains were identified in the archaeological material and compared with modern Stipa tenacissima (esparto grass). Based on direct dating, the fragments of esparto cord from our site are the oldest worked plant fibres in Europe. Sixty fragments of fired clay are described. The clay impressions have allowed us to discuss the making of baskets and containers. According to their attributes and their functional interpretation, we have grouped them into five types within two broad categories, hearth plates and baskets or containers. The clay pieces identified as fragments of containers with basketry impressions are less common than those of hearth plate remains and they are concentrated in the Epipalaeolithic occupation material (13.2-10.2 ka cal вр). The clay impressions from Santa Maira indicate that some fibres were treated or flattened, a preparation process that is known from historical and ethnological sources.
\end{abstract}

Keywords Perishable technologies · Plant fibres $\cdot$ Imprints on clay $\cdot$ Epipalaeolithic $\cdot$ Spanish Mediterranean region

Communicated by F. Antolín.

Electronic supplementary material The online version of this article (https://doi.org/10.1007/s00334-019-00758-x) contains supplementary material, which is available to authorized users.

J. Emili Aura Tortosa

j.emili.aura@uv.es

1 GIUV2015-213, PREMEDOC, Dept de Prehistòria, Arqueologia i Història Antiga, Universitat de València, Av. Blasco Ibáñez 28, 46010 Valencia, Spain

2 Instituto de Historia, CCHS, CSIC, c/ Albasanz 26-28, 28037 Madrid, Spain

3 Museu Valencià d'Etnologia, Carrer de la Corona, 36, 46003 Valencia, Spain

4 Laboratorio de Estudios Paleolíticos, Departamento de Prehistoria y Arqueología, Facultad de Geografía e Historia, Universidad Nacional de Educación a Distancia, Paseo Senda del Rey 7, 28040 Madrid, Spain

5 Valencia, Spain

6 Estudios de Afección Patrimonial, Calle Begoña, 3 - BL, A PTA. 1-1, L’Eliana, 46183 Valencia, Spain

\section{Introduction}

The studies carried out to date on organic and perishable materials have not enabled us to establish a prehistoric sequence of types or organize the history of the evolution of techniques, because they are rarely preserved. Archaeological typologies have been based on remains that tend to survive well, such as pottery and implements of stone or bone, rather than on perishable organic material with infrequent remains. The recognition of the importance of perishable materials for human groups was initially based more on ethnological inferences than on archaeological evidence. The use of such materials for attaching stone and bone tips to lances or spears, and arrow heads used together with a bow, and the presence of needles for sewing seemed logical arguments for their presence (Clark 1952; Clark and Piggot 1965). The use of cordage and scaffolding has been identified in some deep caves, and these materials were probably used in the earliest transport technologies, to tie logs together and form rafts to cross the Wallace Line between Asia and Australia and reach the Sahul (Davidson 2013). More recently, an ivory tool that 
could have been used to make rope has been discovered from the Aurignacian cave deposits of Hohle Fels, Germany (Conard and Malina 2016).

In addition to these inferences, there is also direct evidence. In the Americas, remains of cordage, basketry and textiles from Meadowcroft rockshelter, Paisley caves, Cueva del Guitarrero and Monte Verde etc. have been directly dated to between 12 and $10 \mathrm{ka}$ вP (Adovasio et al. 2014). In the Middle East, Linum usitatissimum (flax) microfibres were identified from Dzudzuana Georgia in cave levels dated to ca. 30 ka вр (Kvavadze et al. 2009). Also, cordage remains were found at Ohalo II, Israel, in a context dated to ca. $19.5 \mathrm{ka}$ вр (Nadel et al. 1994). In Europe, textiles have been identified on some of the so-called Venus figurines and impressions on fire-hardened clay have also been recovered from Gravettian sites in eastern Europe, with a chronology between ca. 28 and 21 ka BP (Adovasio et al. 1996; Soffer et al. 2000).

An age of ca. $17 \mathrm{ka}$ BP was attributed to the cordage identified from Lascaux (Leroi-Gourhan and Allain 1979). In northern Spain, Stone (2011) found evidence from wear on bone tools that they had been used for working perishable materials, while the Antrea net from Finland was directly dated to 9,310 \pm 120 вр (Miettinen et al. 2008). Another direct dating of textiles comes from the cave site of Chertovy Vorota, Russia, and ranges between $8,215 \pm 55$ and $7,710 \pm 50$ вр (Kuzmin et al. 2012). Later in the Holocene, references to finds of tools, wooden structures and plant fibres preserved on coasts and in lakes in northern Europe become increasingly numerous (Fischer 1995; Wigforss 2014). These data show that people developed the technique of plaiting or braiding and twining fibres, which had various applications on different continents and in various situations (Adovasio et al. 2014).

These are materials and techniques that are difficult to recover archaeologically, except in certain specific preservation conditions, and for which we only have a significant corpus of finds from the late Mesolithic, Neolithic and onwards (Piqué et al. 2018). However, the above references indicate that these perishable materials and technologies were in use during the Palaeolithic. In fact, the most abundant direct evidence of this coincides with the expansion of Mode 5 lithic technology, largely defined by the widespread use of microliths as components of composite tools (Clark 1969). These are highly standardized, versatile, multi-functional tools that cannot be dissociated from organic materials (Clarke 1976) and they have also been related to procurement, consumption and maintenance activities (Leroi-Gourhan 1945). The increasing inferences and evidence for fibre-working techniques correspond to the second type of technology applied to materials proposed by Hurcombe (2007), related to the creation of a new object by sticking, tying and knotting various materials; this brings us back to compound tools.
This lack of archaeological visibility contrasts with the importance attributed to these perishable materials and techniques in some ethnoarchaeological studies, which highlight the extremely high proportion of objects made with them and the techniques compared to those made from stone and bone (Collins Jr. 1937; Croes 1997). An example of exceptional preservation of organic materials is found at the Neolithic site of La Draga, Spain (Bosch et al. 2006; Piqué et al. 2018).

By studying this kind of evidence, we can analyse the use of plant fibres and the corresponding techniques used in the western Mediterranean regions of Europe at the end of the Upper Palaeolithic. This region contains some of the driest areas of Europe (Carrión et al. 2012) which is good for preservation of organic remains. The stone working technology at that time was based on blade and bladelet production for making microlithic armatures, components of composite tools. There is extensive evidence for the catching of small prey: rabbits, fish or birds (Aura Tortosa et al. 2009).

Two categories of material evidence are presented in this paper, fragments of braided cord and other plant fibre remains, and fired clay fragments, some showing impressions of plant fibres and smoothed surfaces. The aim of this study is to categorize the materials and techniques used in making artefacts from plant fibres in order to better understand the use of perishable materials among hunting, fishing and gathering societies; these matters affect general issues such as the technology, economy, mobility, storage and social dynamics of these groups.

\section{Archaeological background}

\section{The cave site}

Coves de Santa Maira is located in the central Mediterranean region of Spain (Fig. 1a). It lies $30 \mathrm{~km}$ away from the current coastline at $600 \mathrm{~m}$ a.s.l. at the head of the river Gorgos. Geologically, the area is part of the Prebaetic units situated in the northeast corner of the external zone of the Baetic mountain system, characterized in this area by a high relief of calcareous rocks which became folded during the Alpine orogeny. Over time, these rocks were uplifted, fractured and eroded to form ravines between massive raised limestone cliffs.

The site is a cave formed by a limestone dissolution cavity that is sub-triangular in shape and has a single gallery, ca. $30 \mathrm{~m}$ long and $10 \mathrm{~m}$ wide (Fig. 1b). The cave was divided into two parts, which are called the west sector hall and the Corral del Gordo. The materials presented in this work come entirely from the west sector.

The sedimentary deposit from the west sector is adjacent to a speleothem (a secondary mineral deposit). Its morphology and slope determined the sedimentation of units SM-5 
A
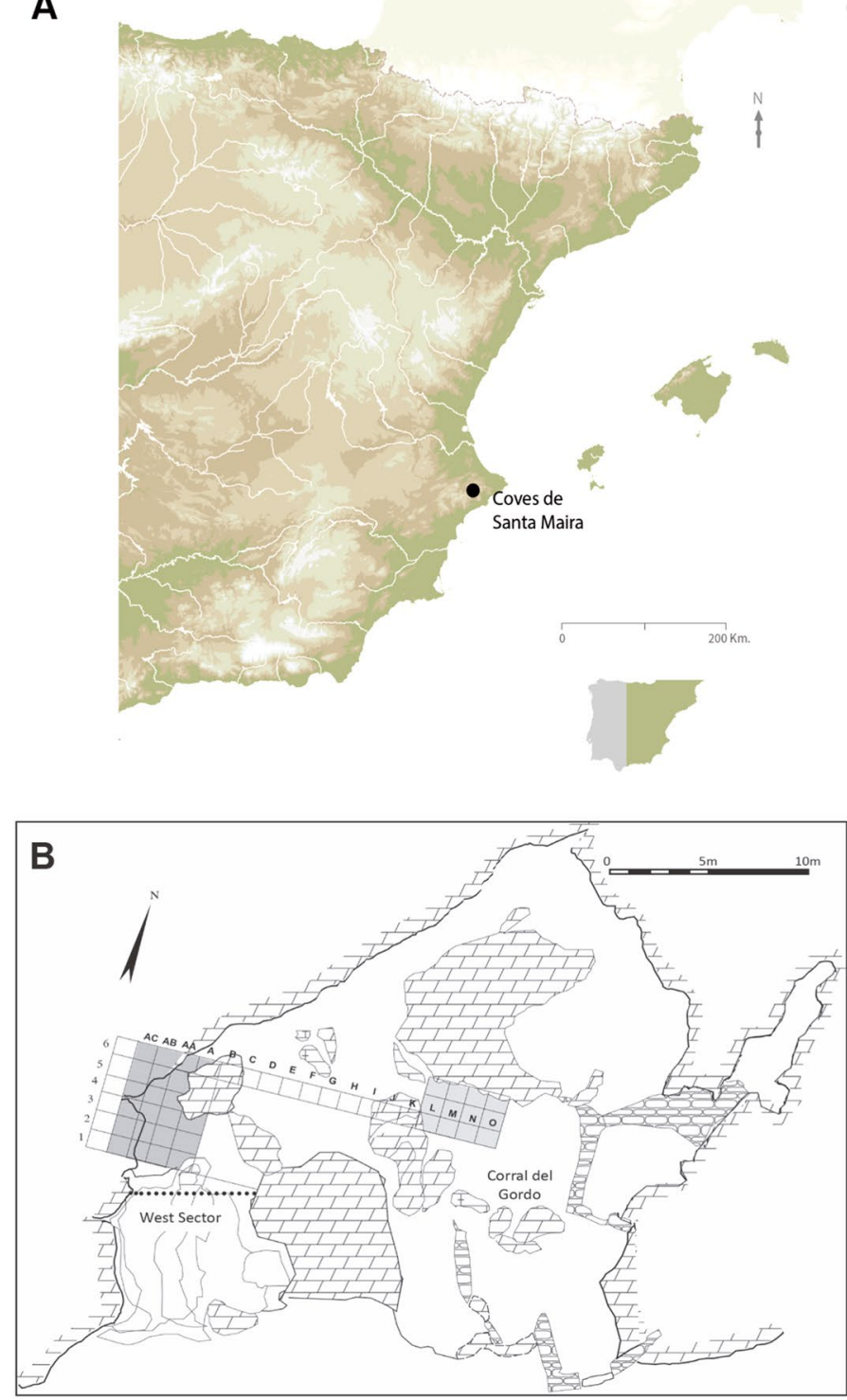

C

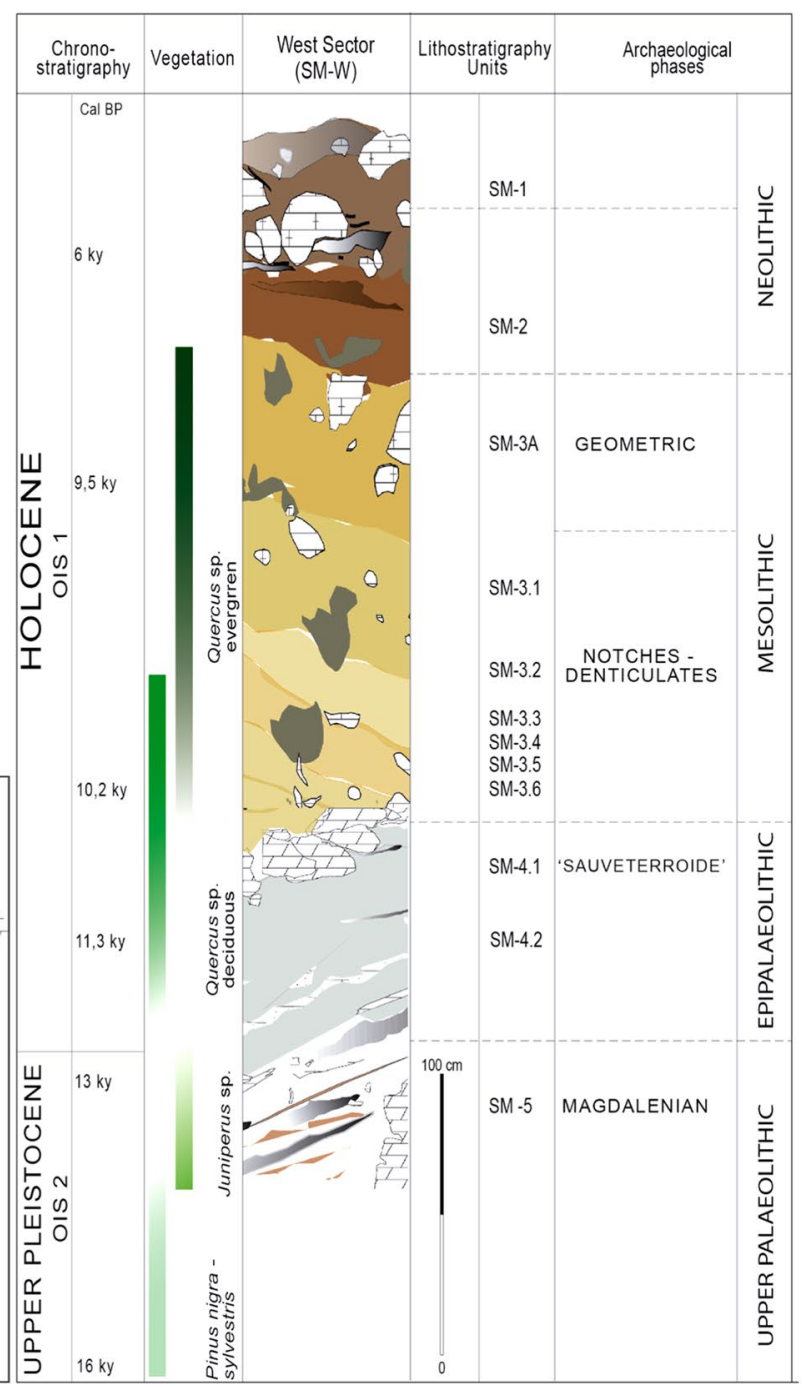

Fig. 1 a location of Coves de Santa Maira (Valencian region, Spain); b plan of the archaeological site; c chronostratigraphy, archaeobotanical data and archaeological phases of the sedimentary sequence of west sector

and SM-4, which form the base and wall of the studied sequence. A lower sub-unit (SM-4.2) has been identified within SM-4, with more angular material and gravel than the upper part (SM-4.1). This upper section has been preserved thanks to the collapse of large limestone blocks, so its distribution beneath them is uneven. In both cases the sediment is strongly affected by human activity, with a substantial presence of organic remains. Unit SM-3 was formed after a fall of large limestone blocks. This deposit lies in a secondary position and slopes steeply into the cave.

The top of unit SM-5 was formed by a series of $1 \mathrm{~cm}$ thick laminations of varying colours. A sample taken of this layer in square AB2 contained carbon spherules $(188 / \mathrm{kg})$ embedded with nanodiamonds (38 ppb), thought to be the Younger
Dryas Boundary layer. It also contained abundant charcoal at $(4.3 \mathrm{~g} / \mathrm{kg})$ and glass-like carbon $(0.7 \mathrm{~g} / \mathrm{kg})$; no magnetic spherules were observed, but the layer contained framboidal spherules $(3,668 / \mathrm{kg})$. The deposition of nanodiamonds and carbon spherules and other kinds of proxy evidence support a hypothesis that there was a major cosmic impact event at $\pm 12,800$ cal вP at the start of the Younger Dryas cooling episode (Kennett et al. 2015).

The west hall archaeological sequence is divided into five major sedimentary units (Fig. 1c; Aura Tortosa et al. 2006), as follows.

- Final Magdalenian, unit SM-5 was deposited, during Greenland Interstadial -1 (GI-1) and Greenland Stadial-1 
(GS-1) (14.7-11.7 ka cal BP), and it is formed by $1 \mathrm{~cm}$ thick laminations of mixed colours, which rest on speleothem.

- Epipalaeolithic, unit SM-4 is formed by shale with sand, some gravel and small limestone pebbles measuring less than $3 \mathrm{~cm}$. The base of unit 4 could be related to the GS-1 (Younger Dryas), dated to 12.9-11.7 ka cal BP, while the upper sequence corresponds to the Preboreal, dated to 11-10.2 ka cal BP.

- Mesolithic, unit SM-3 shows a considerable dip towards the innermost part of the cave. Five sub-units have been identified within this, with a similar grain size and variable colouring. Pebbles and large limestone blocks appear at the base and are separate from unit 4. Radiocarbon dating places it in the Boreal (10.4-8.8 ka cal BP).

- Neolithic, unit SM-2 has an irregular geometry with remains of organic laminations; it was deposited after an erosive event affecting the top of the underlying unit SM-3.

- Chalcolithic to the Middle Ages: unit SM-1 was disturbed and it was strongly eroded over the underlying unit.

The three upper units show considerable bioturbation from the activities of rodents and their predators.

\section{The context of the evidence}

The end of the Palaeolithic in the central Mediterranean region of the Iberian Peninsula was not accompanied by a break in the technology, economy and mobility of human groups (Aura Tortosa et al. 2011). Changes do seem to be evident, though, from ca. 10.5 to $10 \mathrm{ka}$ cal BP, a point at which the term Mesolithic starts to be widely applied (Aura Tortosa 2001).

Epipalaeolithic and Mesolithic occupations in the west hall have yielded important data about the chronology, palaeoenvironment, technology and economy of the inhabitants of the cave during the Pleistocene to Holocene transition. Human occupations have resulted in palimpsests (intermingled layers of evidence), with high densities of all types of remains such as lithic, bones, ornaments, faunal remains, mineral oxides, etc. (Verdasco Cebrián 2016). Changes and variability in these finds assemblages have made it possible to identify two Epipalaeolithic phases (Vadillo Conesa 2018).

The lithic assemblages from unit SM-4 show an integrated production of blades and bladelets, and the blanks would have been used for two large groups of tools, endscrapers/truncated pieces and microliths. The by-product remains are numerous and are present from all the stages of the process.
The identification of bone tools such as needles and awls contrasts with the limited use of projectile points made from red deer antler. Another feature of these occupations is the evidence of ochre working, from collection of the raw material to the grinding stones used for processing it.

According to charcoal studied by Carrión Marco (2005), vegetation in the area of the cave was dominated by junipers and evergreen and deciduous oaks. During GI-1, Juniperus sp. maintained an important presence, but with an increase of Quercus sp. (deciduous and evergreen). From the Preboreal, and especially during the Boreal, riverside taxa such as Salix-Populus and thermophilous ones increase.

The herbivores that were hunted were primarily Capra pyrenaica (Iberian ibex) and then Cervus elaphus (red deer), as well as high frequencies of Lagomorpha (hares and rabbits), a regional small prey (Morales-Pérez 2016). In the final GS-2 occupations, a few remains of Bos sp. (cattle) and Equus sp. (horse) have been identified, and with the advance of the Holocene, there are more animals of woodland, Rupicapra rupicapra (chamois), Capreolus capreolus (roe deer) and Sus scrofa (wild boar).

The west hall has also provided information about the use of plant foods and the transport of marine molluscs and fish to inland sites (Aura Tortosa et al. 2005). These resources have enabled us to identify trends and discuss the concepts of intensification and diversification during the final Palaeolithic and Mesolithic in the Iberian Peninsula (Aura Tortosa et al. 2009).

The density of remains in unit SM-3 is lower and better technology is observed in the carving of local raw materials (Miret i Estruch 2007). More than 30 human remains from at least three individuals have been identified from this unit, scattered and mixed with the faunal remains. Their study has led to the identification of cannibalism (Morales-Pérez et al. 2017). The data obtained show a change in the use of the cave, in technology and economy and also a difference in the mobility of human groups between the Mesolithic unit (SM-3) and those of the late Palaeolithic and Epipalaeolithic (SM-5 and SM-4).

\section{Materials and methods}

We present two categories of material evidence.

- The first comprises four organic fibre items, three partially charred fragments of plaited or braided cord and one piece of raw material which does not show any twisting or work.

- The second group consists of 60 fragments of clay, fired to different degrees. Some show smoothed surfaces as well as impressions of plant fibres, which show a weaving technique with a twining pattern, arranged in rows. 
Fibre remains were only recovered from unit SM-4. The impressions on clay were found in the Final Magdalenian (SM-5), Epipalaeolithic (SM-4) and Mesolithic (SM-3) units. Of the remains that we have described, $71.7 \%$ are from the Epipalaeolithic units, or at the boundary with the Final Magdalenian ones (6.52\%). Unit SM-4 contained not only the largest number of fired clay remains, but also most of the fibre impressions and remains of plant fibres and cordage. Direct dating of the organic short-lived samples places these phases of occupation between 9,370 \pm 40 BP (Beta156021) and 11,600 40 вр (Beta-415937) (Aura Tortosa et al. 2005), and an intermediate date has been obtained for the fragment of cord mentioned above $(10,830 \pm 40$ years BP Beta-438705), which is published for the first time in this paper.

The remaining $21.7 \%$ of the remains of fired clay come from the Mesolithic (SM-3), more specifically from the lower half, in contact with Epipalaeolithic evidence. Several C14 dates on identified charcoal and bone samples place this unit between 8,690 \pm 30 вP (Beta-244010) and 9,060 \pm 30 вР (Beta-416813).

Appropriate procedures have been applied to study each of the materials, by the description of the organic material and the identification of the preserved plant remains and also the study of the fragments of clay with their fibre impressions. Both categories of evidence provide proof of technology related to the making of cordage and basketry.

\section{Cord and fibre materials}

The analysis of these materials requires the use of accurate terminology and careful illustration (King 1978). The cordage has been described and classified according to the terminology and descriptive criteria of Adovasio (2010), Emery (2009), Hurley (1979), Carr and Maslowski (1995) and Jolie (2014), following the descriptions of similar remains found at La Draga by Piqué et al. (2018) and Cova des Pas (Romero-Brugués et al. 2018).

Finally, we compare historical and ethnographic data (Kuoni 1981) with the techniques and processes identified from the cord remains and fired clay impressions similar to Stipa tenacissima (esparto grass) from Coves de Santa Maira.

\section{Botanical identification}

This was carried out by observing the plant fibres with a reflected light bright field/dark field optical microscope using magnifications ranging from $50 \times$ to $1,000 \times$ and with a Hitachi S-4100 scanning electron microscope (SEM). With these methods, the features and measurements of the archaeological plant remains were compared with those of modern samples of $S$. tenacissima leaves and with specialist literature on plant anatomy (Metcalfe 1960; Schweingruber 1990). S. tenacissima was chosen for comparison because it is one of the plants that has traditionally been most widely used for this purpose (ESM; Alfaro Giner 1984; Barber Vallés 2001); all the families and species in the monocotyledons are anatomically very similar and are difficult to distinguish from one another (Schweingruber 1990), so $S$. tenacissima is representative of the structure that we found.

\section{Study of imprinted fragments of fired clay}

The fragments of clay, with and without impressions, were observed with a Leica M165C stereo microscope and photographed for analysis. It was not considered appropriate to make positive casts according to the methods described by Drooker (1992, pp 251-254), bearing in mind the risks discussed by Rieth (2004) regarding the effects on these fragile fragments and their potential contamination. The measurements were made directly on the image captured by the microscope using Leica Application Suite v. 3.

The identifiable impressions were categorized by technological type according to the procedures in Adovasio (1977, 2010), Emery (2009), Hurley (1979) and Desrosiers (2013). Moreover, a comparison has also been made with ethnographic sources on the use of esparto grass in order to try to define the techniques used in making the archaeological samples.

\section{Results}

The fibres were recovered in two assemblages. The first consists of remains of fibres of uneven lengths (12-23 mm) that are only slightly twisted at one end, while the second consists of three fragments of a cord on which it is possible to identify a number of common traits, despite their variable state of preservation: the same type of fibres with a similar braiding pattern and the same dimensions. These elements suggest that they may have formed part of the same object (ID 61). Moreover, they were found together (Fig. 2).

The largest of the three fragments (length $3.7 \mathrm{~cm}$, width $0.3 \mathrm{~cm}$, ID 61 a, Fig. 2) has a regular, compact, braided structure formed by three bunches of fibres and was made by means of an oblique interlacing or braiding technique (Emery 2009; Adovasio 2010; Jolie 2014). Each one comprises 10-14 fibres. No previous twisting was observed on each of the braided strands and so the fibres must therefore have been incorporated and braided to the desired length.

The second fragment has the most poorly preserved braided structure, but its characteristics are shared with 
Fig. 2 a-c fragments of cordage from Coves de Santa Maira, unit SM-4 (ID 61). Fragment $b$ was used to obtain a direct AMS date (scale bar $=1 \mathrm{~mm}$ )

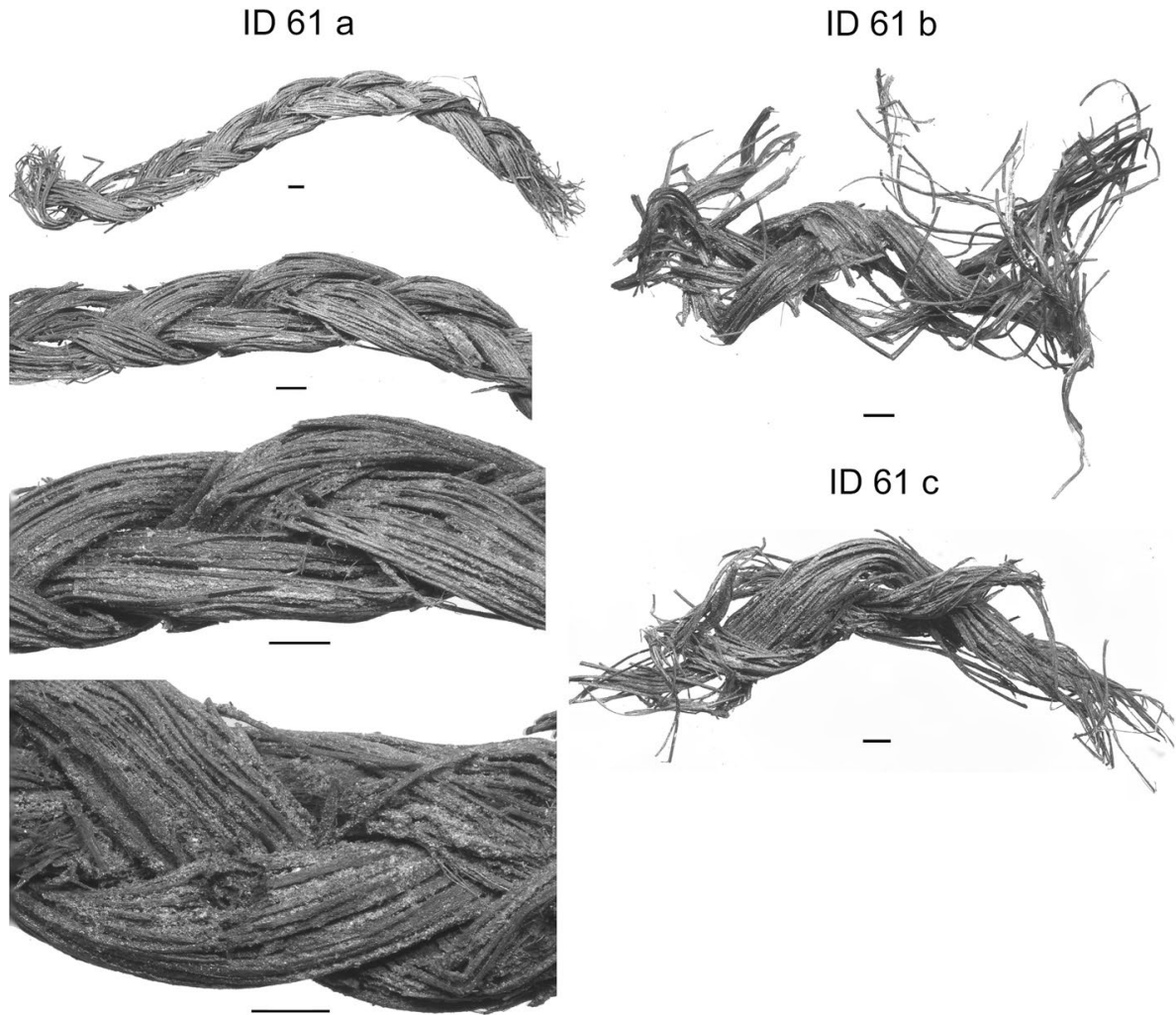

those described so far (length $1.8 \mathrm{~cm}$, width $0.3 \mathrm{~cm}$, ID 61 b, Fig. 2).

The third fragment does not have such a compact structure as the first one and shows frayed ends (length $2.2 \mathrm{~cm}$, width $0.4 \mathrm{~cm}$, ID $61 \mathrm{c}$, Fig. 2). All the fibres recovered from unit SM-4 belong to the same taxon.

\section{Botanical identification and dating of organic materials}

A sample of braided plant fibres was taken from a fragment for its botanical identification (Fig. 2b). It was not possible to observe the fibres in cross-section due to their lack of consistency. However, study of the longitudinal sections of the fibres under both a microscope with reflected light illumination and SEM suggests that they are from a monocotyledon, probably from the Poaceae and, more specifically, from the leaves of the plant. The anatomical features of this group of plants were identified and compared with modern $S$. tenacissima samples (Fig. 3).

In long, narrow monocotyledon leaves the epidermal cells are usually elongated parallel to the axis of the leaf and the stomata are arranged in longitudinal rows in the intercostal areas (between the veins). Xerophytic (dry habitat) grasses have numerous stomata on the upper (adaxial) surface and some larger bulliform cells, the function of which is to protect the leaves from drying out (Evert and Eichhorn 2006). The leaves roll up in dry conditions to protect the upper surface and slow transpiration (Fig. 3, photo 2). Most of the stomata and trichomes (hairs, scales or glands on the epidermis or leaf surface) are found on the underside of the leaf. The SEM images corroborate the identification as esparto or a similar grass.

The fragments of cordage were treated with Paraloid acrylic resin at the Museu Arqueològic Municipal d'Alcoi to preserve their integrity. We consulted the Beta Analytic dating laboratory about the effects of this treatment on the results of the radiocarbon dating. They confirmed that they use a pre-treatment that can remove the organic resin effectively, thus allowing dating by AMS.

The result obtained was 10,830 \pm 40 вр (Beta-438705), with a calibrated age (68\% probability) of $12,730-12,710$ cal BP. This result makes the fragment of grass cord found at Coves de Santa Maira the oldest directly dated evidence of the use of braided plant fibres in Europe. At the same time, this means that the clay fragments with plant fibre impressions from the same stratigraphic context can be regarded as part of the same technical process and similar in date. 

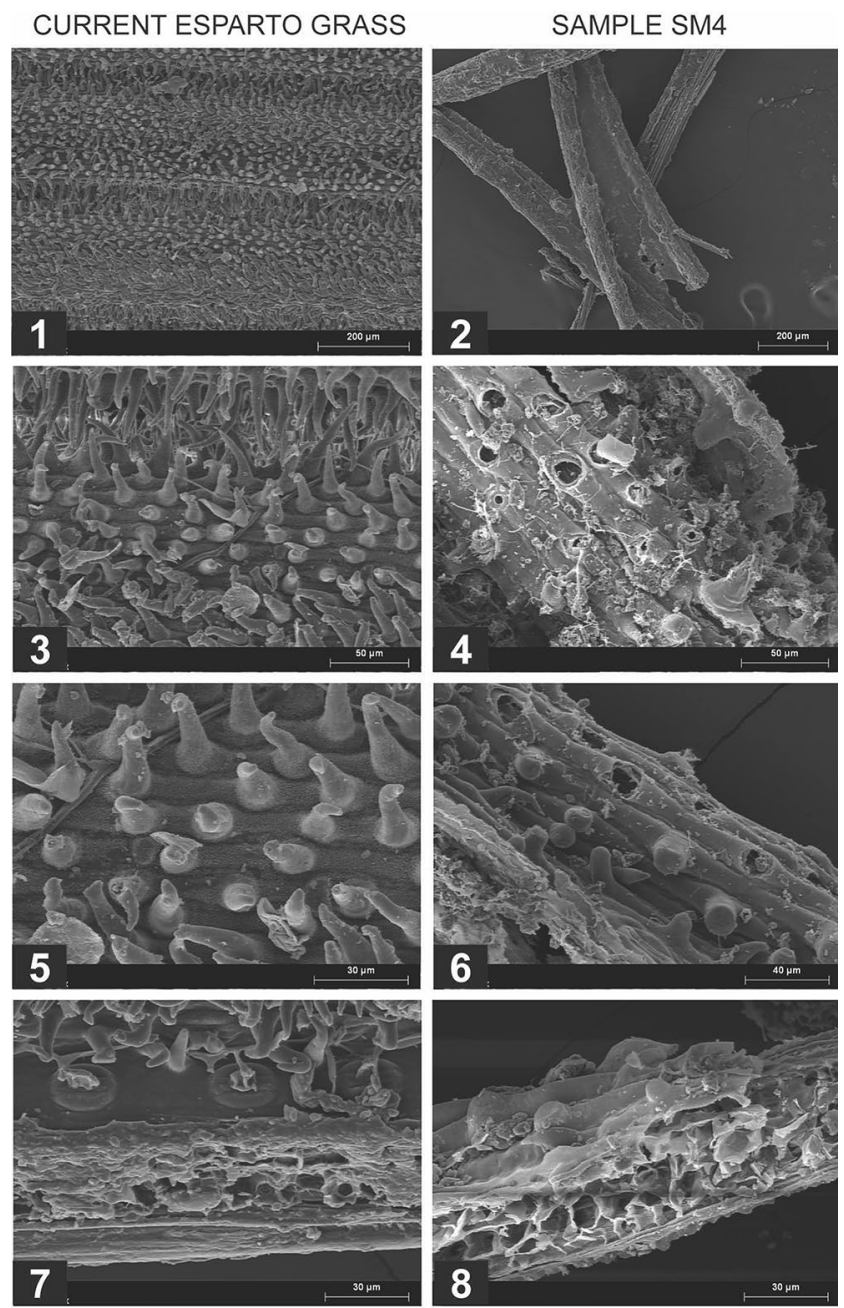

Fig. 3 SEM images comparing modern S. tenacissima and plant fibres from Santa Maira SM-4 (ID 61b). Recent S. tenacissima. 1, overview of the abaxial (upper) surface of the leaf (magnification $\times 130) ; 3$ and $\mathbf{5}$, details of simple filiform trichomes $(\times 450$ and $\times 900)$; 7 , cross-section of the leaf and detail of the stomata $(\times 800)$. Santa Maira sample (ID 61b); 2, leaf fragments folded towards the adaxial (lower) surface $(\times 100) .4$ and $\mathbf{6}$, details of the trichomes $(\times 500$ and $\times 600)$. 8. Cross-section of the leaf $(\times 800)$

\section{The fired clay remains}

Based on their morphology and observed features, such as signs of thermal alteration, state of the surfaces, presence of fibres and impressions, we have classified the fired clay remains into five types (Figs. 4, 5; ESM Table 1). This diversity is indicative of a wide range of possible uses of the clay in the domestic setting. According to their attributes and functional interpretation, we have grouped the remains into two broad categories: hearth plates (Types 1-2) and baskets/ containers (Types 3-5), as follows.

- Type 1 fragments are smoothed on one surface and untreated on the other. Some of them have plant impressions on their smooth surface or inside them, showing that they were made using a mixture of clay and plant material (Fig. 4). Additionally, the presence of laminations caused by the heating or firing process is often seen in cross-section.

- Type 2 includes fragments whose surfaces show no kind of treatment. However, the presence of plant temper as a binder and lamination due to the effects of fire have been identified (Fig. 4).

- Type 3 fragments of fired clay have a smoothed outer surface, while there are impressions of basketry on the inner, more convex surface. The impressions follow a pattern in the only two pieces included in this type. Longitudinal bundles of fibres are intertwined transversely with an apparently flexible element, which corresponds to open simple twining with s-twist wefts (Fig. 5).

- The longitudinal impressions on item 56 are between 0.8 and $1.2 \mathrm{~mm}$ wide and are rounded, although one part has a greater width (1.5 mm) and a midrib (Fig. 5). The measurements correspond to those of a S. tenacissima leaf. Due to the state of preservation of item 57, it is not possible to obtain measurements of these fibres. However, the distance between the transverse lines varies between $5.7 \mathrm{~mm}$ for item 42 and $9 \mathrm{~mm}$ for item 43 .

- A single fragment represents Type 4; it is similar to Type 3, with a convex, smoothed outer surface, and a concave inner surface, but in this case there is no basketry impression (Fig. 5).

- Type 5 corresponds to two fragments of the same item, with an altered outer surface on which unordered plant impressions are observed, from plant material which must have been mixed with mud as a binder (Fig. 5). There are basketry impressions on the concave inner surface, following the pattern defined in Type 3. The difference in this case is the width of the longitudinal lines, which are longer $(4.2-4.4 \mathrm{~mm})$, with a distance of 7.8 to $6.6 \mathrm{~mm}$ between the transverse lines, and there are a number of longitudinal incisions in the impressions that in some cases show how these fibres were twisted.

The woven basketry structures impressed on Types 3 and 5 appears to correspond to the same technique, combining the use of paired weft elements and open and close twining in each of the fragments (Fig. 5). The structure corresponds to a series of vertical warps that are tied as paired horizontal weft elements, a very common weave structure (Jolie 2014, Fig. 8.4).

The fibre remains and clay fragments appear concentrated in $4 \mathrm{~m}^{2}$ of the $17 \mathrm{~m}^{2}$ area excavated. This location could be related to topography and natural lighting (Fig. 6). 

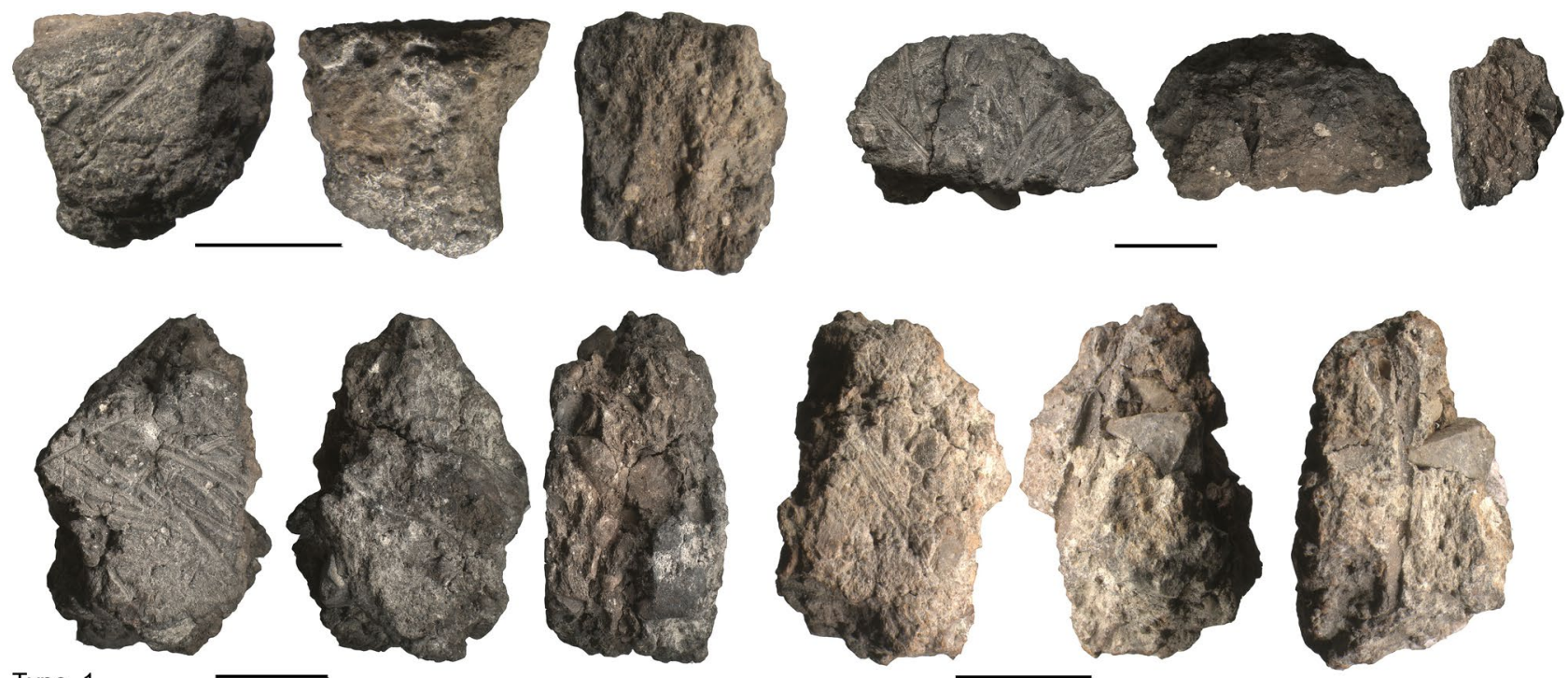

Type 1

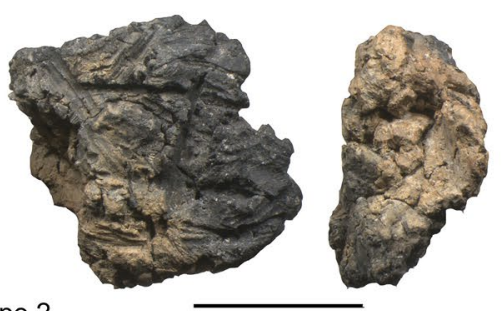

Type 2

Fig. 4 Coves de Santa Maira, fired clay types $1-2$ (scale bar $=1 \mathrm{~cm}$, see ESM Table 1)

\section{Discussion}

\section{Cords, mats, baskets or containers}

In this study, we have presented evidence, both directly from fibres and indirectly from imprints in clay found at the Santa Maira cave site, of the use of plant fibres for making artefacts. The study has revealed that these were very probably Stipa tenacissima (esparto grass), a species which was traditionally used for making various useful things such as cordage, basketry etc.

These remains reflect the long tradition of using plant fibres in the Mediterranean region of the Iberian Peninsula to make a wide variety of artefacts.

Bunches of 3-strand braided fibres have been identified in the three fragments of cord, which may have been part of the same artefact; the interlacing of each bundle has been observed. Taxonomic study of the material indicates that this could be $S$. tenacissima, a plant with a Mediterranean distribution, or another very similar grass. Cordage made from of 3-strand braided fibres is widely documented in various contexts and chronologies (Jolie 2014). These finds are the oldest evidence of cordage and basketry identified and dated in this geographical area so far. Previously, evidence of the use of basketry has been limited to the Neolithic and later prehistoric periods together with classical antiquity (Alfaro Giner 1984; Piqué et al. 2018; Romero-Brugués et al. 2018).

The artefacts in question are fragments of fibres that were plaited or braided. The technique of making one cord is simple, but multiplying and combining different cords involves more complex techniques of basketry and weaving (LeroiGourhan 1945; Adovasio 1977; Emery 2009). This was the approach taken when studying the plant impressions from Dolni Vestonice I and II and Pavlov I (Soffer et al. 2000), in which basketry was considered as a subclass of weaving methods that were used to produce containers, bags and mats. The fundamental difference in contrast to textile fabrics is that basketry is woven manually, without the use of any kind of frame or loom. Fabric is a more flexible material woven by using some kind of hanging or horizontal weaving frame. As mentioned in numerous works, the distinction between basketry and woven fabric can only be identified on well-preserved artefacts and is quite imprecise in the case of impressions on clay, which are almost always incomplete and small (Soffer et al. 2000). 


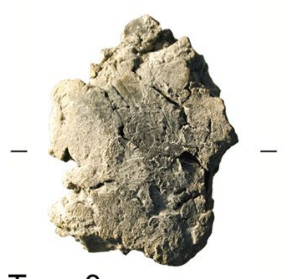

Type 3

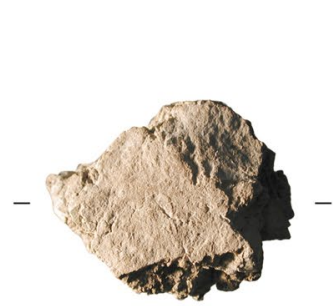

Type 4
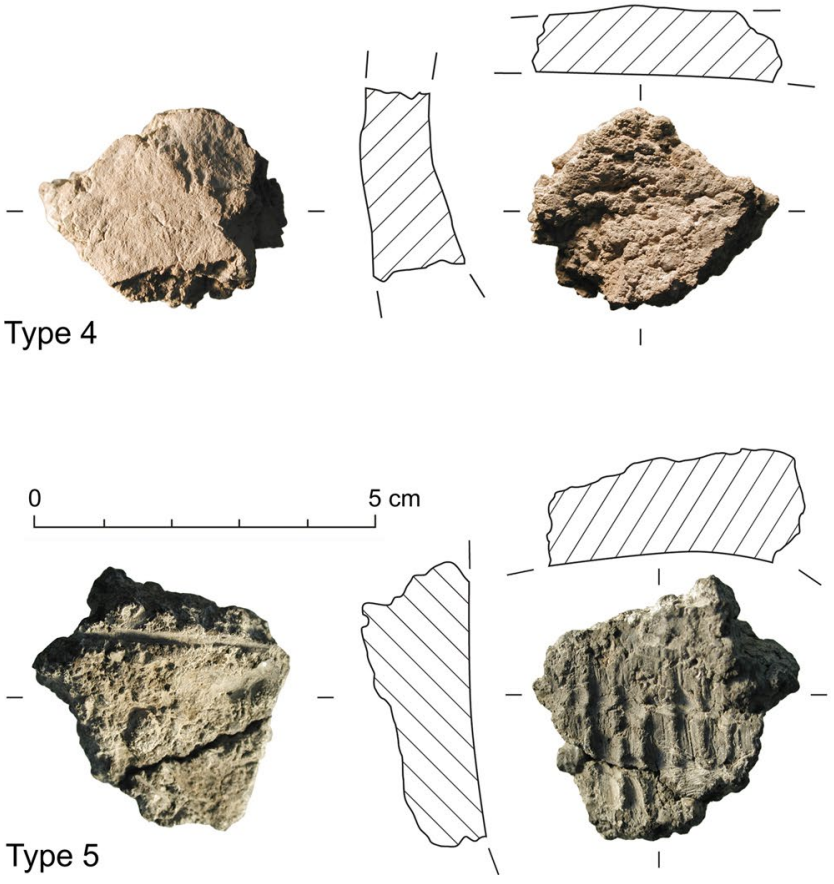

Fig. 5 Coves de Santa Maira, fired clay types 3-5 (scale bar $=5 \mathrm{~cm}$ with $1 \mathrm{~cm}$ divisions) (ESM Table 1)

The fragments of cordage from Santa Maira might represent the use of cords to bind arrows which could have been fired with a bow (Rozoy 1978), among many other applications. But in this case, the clay impressions from cords could represent mats, flexible containers or rudimentary textiles. There are numerous questions about the use of such cordage for making baskets and carrying equipment such as bags or backpacks, etc. and even for clothing; dresses or sandals might be represented by our remains, similar to those known from the south of the Iberian Peninsula in the Neolithic (cf. Alfaro Giner 1984) or the Capsian context in North Africa (Morales et al. 2015), but several millennia later than the remains described here.

The clay fragments from Santa Maira fall into two categories. The first (Types 1 and 2) are possibly parts of hearth plates, a common archaeological find. They are interpreted as fragments of hearths of which the smoothed surface was preserved (Type 1) and fragments of any other structure built from clay that subsequently came into contact with fire (Type 2). They comprise a surface made from mixing clay with some kind of plant temper that acted as a binder. The firing is the result of occasional or constant application of heat to the clay. There may not have been any intention of making a fired clay item or structure, in which case the artefact in question would be the result of combining clay, plant fibres and applying heat. Most of the fragments have plant impressions on their smooth surface or inside, and are dated to the Mesolithic (Table 1).

The second category, (Types 3-5) consists of impressions from fragments of mats or baskets made with braided cords. The greatest limitation to working out how they were made and for what purpose is the small size of the fragments. Nevertheless, the more or less concave section and profile of Types 3 and 5 could be the impression of a rope mat made with braided cords (Fig. 5). Due to their flexibility, pieces of basketry could have been laid on uneven ground, which may explain this concave section. However, the treatment of the other surface of the clay to the plant impressions is not consistent with this idea.

These fired clay fragments with treated surfaces and impressions of braided fibres are compatible with the making of clay containers, using the basketry as an internal structure upon which to build them, but in this case either a wider fibre has been used or it is the same fibre which had previously been flattened. The impressions resemble the fragments of plant fibres described above. Type 4 shares these features, but in this case either no inner basketry structure was used, or it corresponds to an area where there was no framework of plant fibres.

The morphology and width of the fragments of cord closely match those of the imprints on fired clay. Even though the impressed fragments are small, we believe they may be oriented according to the vertical position of the warp and the horizontal position of the paired weft elements. Historical data on basket weaving processes and ethnographic collections support this observation (Barber Vallés et al. 1997). In addition, it has been possible to identify from such small fragments the process by which the probable $S$. tenacissima was prepared, either fresh, immersed in water, plaited or crushed. In the remains described above, we have identified two ways in which plant fibres were used to make objects. In one, the leaves were twined roughly, without previous flattening, whereas in the other the leaves were flattened. These are the two methods that continue to be used today to work with plant material such as S. tenacissima (Fig. 7). The identification of these features suggests that the fragments correspond to two different objects.

This second group (Types 3-5) shows the development of basketry based on indirect evidence, from imprints in fired clay. Thus, it is likely that the braided fibres identified among the plant remains were used to make different kinds 
Fig. 6 Coves de Santa Maira. Distribution plan of the materials analysed. In the upper part, distribution of fired clay. In the image below, distribution of plant fibres and cordage (ESM Table 1)

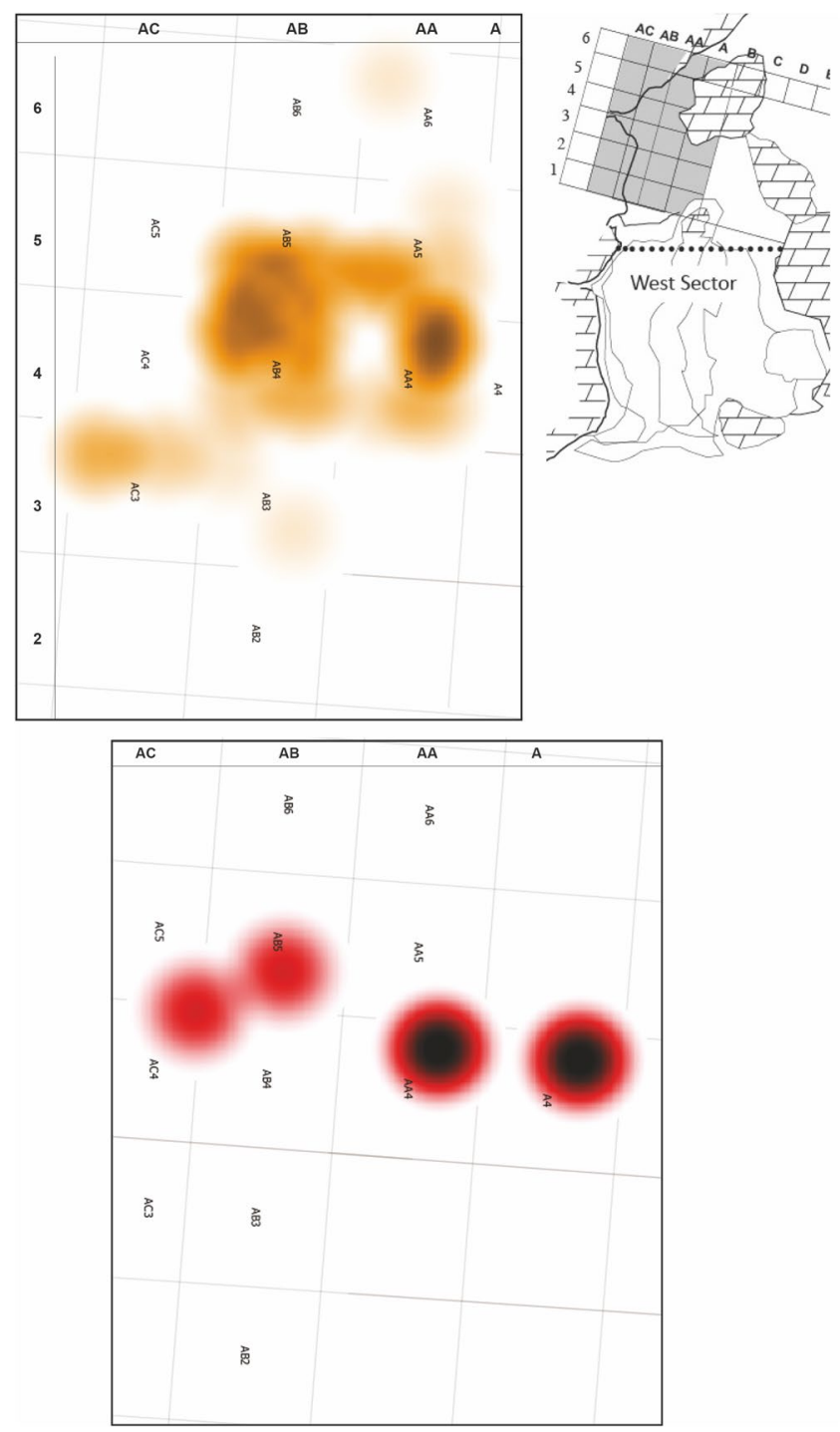

Table 1 Classification of clay fragments and plant fibres based on their morphology

\begin{tabular}{|c|c|c|c|c|c|c|c|c|c|}
\hline \multirow{2}{*}{$\begin{array}{l}\text { Stratigraphic } \\
\text { units }\end{array}$} & \multirow[t]{2}{*}{${ }^{14} \mathrm{C}$ dates (ka cal вр) } & \multirow[t]{2}{*}{ Archaeol. phases } & \multicolumn{2}{|c|}{ Hearth plates } & \multicolumn{3}{|c|}{ Baskets or containers } & \multirow{2}{*}{$\frac{\text { Fibres }}{\text { Twined }}$} & \\
\hline & & & Type 1 & Type 2 & Type 3 & Type 4 & Type 5 & & \\
\hline \multirow[t]{2}{*}{ SM-3 } & $10.4-8.8$ & Mesolithic & 3 & 5 & & & & & \\
\hline & & $\mathrm{M} / \mathrm{E}$ contact & 2 & 3 & & & & & \\
\hline SM-4 & $12.9-10.2$ & Epipalaeolithic & 16 & 19 & 2 & 1 & 2 & $1(3)$ & 1 \\
\hline SM-5 & $14,7-13$ & Final Magdalenian & 6 & 1 & & & & & \\
\hline Sum & & & 27 & 28 & 2 & 1 & 2 & $1(3)$ & 1 \\
\hline Total & & & 55 & & 5 & & & 4 & \\
\hline
\end{tabular}

Their characteristics are described in the text

of objects, including baskets and containers. The remains identified as fragments of containers with basketry impressions are less common than those of hearth plate remains and they are concentrated in the Epipalaeolithic levels. Their stratigraphic distribution does not correspond to a single event, such as making the cords, the flexible containers and the coated clay. However, the combination of this archaeological evidence allows us to propose the existence of various stages of the same technical process. 

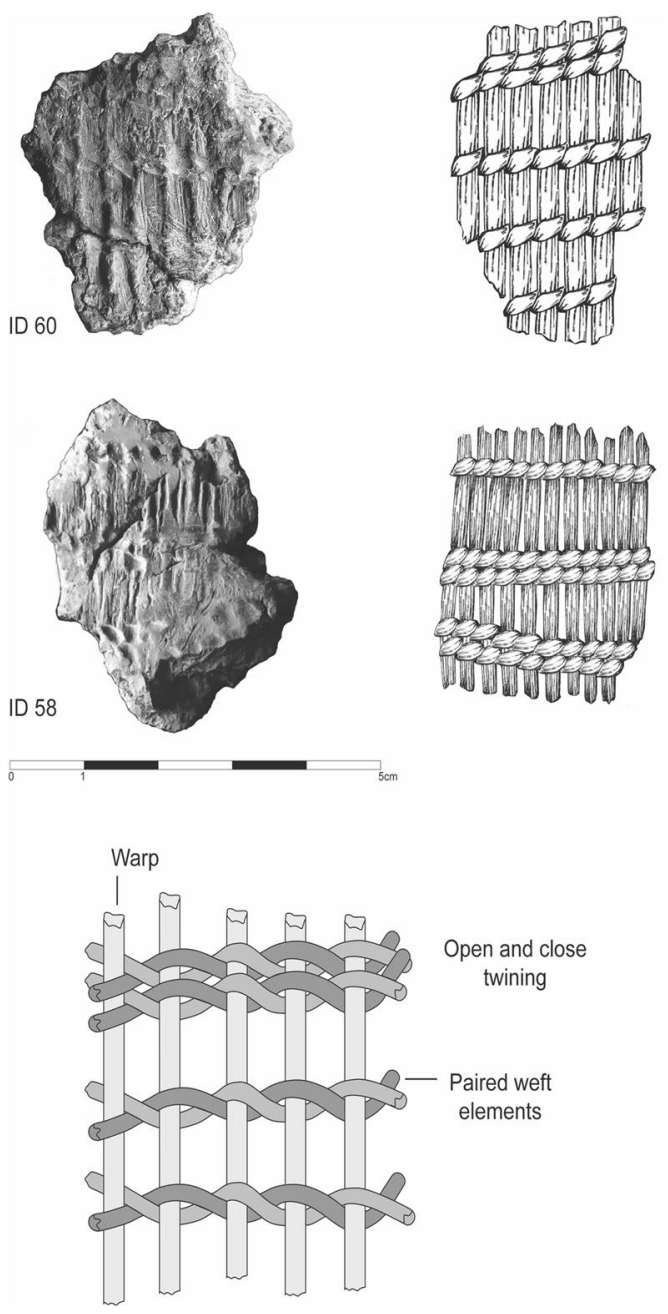

Fig. 7 Twined fibre imprints on clay from Santa Maira (ID 60 and 58) on the left and an illustration on the right. Below, the twining structure is shown

In addition to making baskets or containers with S. tenacissima fibres, the fragments with imprints show how flexible containers would have been coated in clay. We do not have any evidence to show what they were used for, but ethnographic information from Morocco confirms the use of such containers for storing liquids (I. Ziani, personal communication). Mud or animal fat could have been used to seal the container and prevent liquid from leaking out.

We do not know whether the firing of this clay coating on the containers was accidental or intentional. As found in western Russia, flexible containers seem to have been used as moulds for making the first pottery (Zhushchikhovskaya 1997; Kuzmin 2006). But the firing could also have been unintentional if the clay containers were used for cooking or came into contact with fire accidentally.

Beside the data cited above, there is another reference to the firing of clay to make the animal figurines found at the Epigravettian site of Vela Spila, Croatia, dated to $17.5-15 \mathrm{ka}$
$\mathrm{BP}$, which the authors relate to the Pavlovian-Gravettian tradition (Farbstein et al. 2012). In this case, these working processes are linked to the creation of shapes and designs that seem to be symbolic or connected with beliefs, whereas the materials presented here seem to have had a more domestic or utilitarian purpose.

In any case, there is no evidence that enables us to relate the possible containers described here to Neolithic impressed pottery, the coastal expansion of which dates to around $7.5 \mathrm{ka}$ cal вр (Isern et al. 2017), far later than the evidence presented in this paper.

A small number of imprints have been identified, leading to discussion as to whether the use of clay to reinforce flexible containers could be considered evidence of the development of a technology that was intended for storage purposes. In this case, the clay containers would have been heavier and more fragile than the flexible ones. Their use as pots for storing or cooking liquids, as well as for carrying them, seems to be a plausible purpose. Since the cave would only have been occupied periodically by these nomadic people, these containers would have remained there, only being used during periods of occupation. The making of these containers may have been a seasonal activity, as well.

Ingold (1983) discussed the development of storage (population increase, sedentism, trade and risk buffering) and proposed three storage categories (ecological, practical and social storage), of which practicality is the one that is most consistent with the remains found at Santa Maira. It would have been a solution that required little maintenance. It also sheds light on how human groups would have used the land and its resources, particularly the intensive hunting of small prey (Aura Tortosa et al. 2002, 2009; Morales-Pérez 2016), gathering useful plants (Aura Tortosa et al. 2005) and obtaining marine fish and shellfish (Aura Tortosa et al. 2016). Transport of these resources from the coast or their relationship with the gathering and processing of fruits, nuts and seeds (Geib and Jolie 2008) may be other possible uses of basketry. These relate to two of the types of indirect evidence of the use of storage discussed by Rowley-Conwy and Zvelebil (1989).

The relationship between technologies using perishable materials, means of storage, regional mobility patterns and social complexity are other aspects discussed in the literature (Cunningham 2011). In fact, general models have been proposed with various levels of complexity, from highly mobile groups to sedentary territorial groups that practised storage (Rowley-Conwy 1999). In the case of Santa Maira, the data on the sources of the raw materials for the carved stone industry and marine resources brought from the coast point to the combined use of both coastal areas and ones at middle altitudes in inland valleys. These data suggest increasing territoriality towards the end of the Palaeolithic in this region, an idea that is now supported by this evidence of organic 
materials, which may have played a part in short-term storage strategies.

Another important aspect that has been covered by numerous works on perishable materials is the matter of who would have done the work with clay and basketry. The ethnological and ethnohistorical data suggest that this may have been a female task (Conkey 1991; Soffer et al. 2000; Adovasio et al. 2007), although in our case, we have no data to approach this issue.

\section{Conclusions}

The fibres recovered from unit SM-4 belong to the same taxa as the braided fibres, so we consider that all of them were selected for their particular qualities. They were gathered and brought to the cave by the human groups that inhabited it, and made into basketry.

Evidence of the use of plant fibres by prehistoric hunters, fishers and gatherers is scarce and often indirect. The recovery of these artefacts has enabled us to reconsider the lack of visibility in the archaeological record of the things made from perishable organic material during the Palaeolithic and Mesolithic periods. Most works on technologies with these materials suggest that they would have formed parts of artefacts, working processes and various economic and social activities, which may have been vital for the survival and identity of the societies that produced them. However, the direct evidence from perishable materials is very scarce, thus preventing us from making inferences about their involvement in various processes.

The plant fibres from Santa Maira had been braided to create a cord using a plaiting technique and they are the earliest dated evidence of their kind for western Europe. The taxonomic identification indicates that these fibres are from $S$. tenacissima or another closely related grass. The evidence discussed here comes from an archaeological site which was recurrently occupied at certain times by small groups of hunter-gatherers from around $16 \mathrm{ka}$ cal BP, while they used coastal and mid-mountain resources.

In addition to the twined plant fibres, we have described fragments of fired clay that can be grouped into two broad categories based on their features. The most frequent includes fragments that we have related to the use of clay within a domestic setting, possibly fragments of hearth plates. The second is represented by a few fragments indicating that the application of clay to containers made from plant fibre was a practice that may have been linked to the need for vessels capable of holding liquids or even for cooking. It cannot be confirmed whether the firing of these vessels was accidental or intentional.

We do not know of any references from anywhere else in southern Europe about the identification of braided cord made from esparto or a similar grass, or fired clay impressions from cultural and chronological contexts like the ones described in this work. These data reveal the bias involved in the rarity of perishable materials from European Palaeolithic and Mesolithic contexts due to poor preservation of organic material, so our knowledge about cultural material made from leather, wood or plant fibres and the techniques used to make them remains weak and fragmented. Our evidence for the use of these materials has important implications, as it enables us to carry out a more detailed analysis of storage, regional mobility systems and social complexity of European Palaeolithic societies.

Acknowledgements This work is funded by the NPI of the Ministerio de Economía, Industria y Competividad (Project: LongTransMed, HAR2013-46861-R) and Generalitat Valenciana (Project: AICO/2018/125). Y. Carrión Marco is beneficiary of a Ramón y Cajal research fellowship funded by the Ministerio de Economía, Industria y Competividad. We are very grateful to the reviewers for their helpful comments on this paper. We would like to thank Edward A. Jolie for his valuable comments. We acknowledge for their help Lluís Molina for drawing Fig. 5 and Pilar Mas for Fig. 7. The braided cord was found by Isabel Carbayo and the uncharred plant fibre remains by M. Lucrècia Centelles. Finally, thanks to Servei Central de Suport de la Investigació Experiemental of the University of Valencia.

Open Access This article is distributed under the terms of the Creative Commons Attribution 4.0 International License (http://creativeco mmons.org/licenses/by/4.0/), which permits unrestricted use, distribution, and reproduction in any medium, provided you give appropriate credit to the original author(s) and the source, provide a link to the Creative Commons license, and indicate if changes were made.

\section{References}

Adovasio JM (1977) Basketry technology: a guide to identification and analysis. Aldine Publishing, Chicago

Adovasio JM (2010) Basketry technology: a guide to identification and analysis, updated edn. Left Coast Press, Walnut Creek

Adovasio JM, Soffer O, Klíma B (1996) Upper paleolithic fibre technology: interlaced woven finds from Pavlov I, Czech Republic, c. 26,000 years ago. Antiquity 70:526-534

Adovasio JM, Soffer O, Page J (2007) The invisible sex: uncovering the true roles of women in prehistory. Smithsonian Institution, Washington, DC

Adovasio JM, Soffer O, Illingworth JS, Hyland DC (2014) Perishable fiber artefacts and Paleoindians: new implications. N Am Archaeol 35:331-352

Alfaro Giner C (1984) Tejido y cestería en la península Ibérica. Historia de su técnica e industrias desde la Prehistoria hasta la Romanización (Bibliotheca Praehistorica Hispana 21). CSIC, Instituto Español de Prehistoria, Madrid

Aura Tortosa JE (2001) Cazadores emboscados. El Epipaleolítico el País Valenciano. In: Villaverde V (ed) De Neandertales a Cromañones. El inicio del poblamiento humano en tierras valencianas. Universitat de València, Valencia, pp 219-238

Aura Tortosa JE, Villaverde V, Pérez M, Martínez R, Guillem P (2002) Big game and small prey: Paleolithic and Epipaleolithic economy from Valencia (Spain). J Archaeol Meth Theor 9:215-268 
Aura Tortosa JE, Carrión Y, Estrelles E, Pérez-Jordà G (2005) Plant economy of hunter-gatherer groups at the end of the last Ice Age: plant macroremains from the cave of Santa Maira (Alacant, Spain) ca. 12000-9000 B.P. Veget Hist Archaeobot 14:542-550

Aura Tortosa JE, Carrión Marco Y, García Puchol O et al (2006) Epipaleolítico-Mesolítico en las comarcas centrales valencianas. In: Alday A (ed) El mesolítico de muescas y denticulados en la cuenca del Ebro y el litoral mediterráneo peninsular. Diputación Foral de Álava. Departamento de Cultura, Vitoria-Gasteiz, pp $65-118$

Aura Tortosa JE, Jordá Pardo JF, Morales Pérez JV, Pérez Ripoll M, Villalba MP, Alcover JA (2009) Economic transitions in finis terra: the western Mediterranean of Iberia, 15-7 ka BP. Before Farming 2(4):1-17

Aura Tortosa JE, Jordá Pardo JF, Montes L, Utrilla P (2011) Human responses to Younger Dryas in the Ebro valley and Mediterranean watershed (Eastern Spain). Quat Int 242:348-359

Aura Tortosa JE, Jordá Pardo JF, Álvarez-Fernández E et al (2016) Palaeolithic Epipalaeolithic sea people of the southern Iberian coast (Spain): an overview. In: Dupont C, Marchand G (eds) Archéologie des chasseurs-cueilleurs maritimes: de la fonction des habitats a l'organisation de l'espace litoral. Société préhistorique française, Paris, pp 69-92

Barber Vallés A (2001) Proposta de tipificació de les manufactures amb espart (Stipa tenacissima L.) al territory valencià (I). In: Revista Valenciana de Folklore, vol 2. Associació d'Estudis Folklòrics Grup Alacant, Alacant, pp 95-117

Barber Vallés A, Cabrera González R, Guardiola i Mora I (1997) Sobre la cultura de l'espart al territori Valencià. Fundació Bancaixa, València

Bosch A, Chinchilla J, Tarrús J (coords) (2006) Els objectes de fusta del poblat neolític de la Draga. Excavacions de 1995-2005. CASC-Museu d'Arqueologia de Catalunya, Girona

Carr C, Maslowski RF (1995) Cordage and fabrics: relating form, technology and social processes. In: Carr C, Neitzel JE (eds) Style, society and person, archaeological and ethnological perspectives. Plenum Press, New York, pp 297-343

Carrión Marco Y (2005) La vegetación mediterránea y atlántica de la península Ibérica. Nuevas secuencias antracológicas. (Serie de Trabajos Varios 104). Servicio de Investigación Prehistórica, Valencia

Carrión JS, Fernández S, González-Sampériz P et al (2012) Paleoflora y paleovegetación de la Península Ibérica e Islas Baleares: Plioceno-Cuaternario. Ministerio de Economía y Competitividad, Madrid. Fundación Séneca, Agencia Regional de Murcia, Murcia. http://paleofloraiberica.net/INICIO.html

Clark JGD (1952) Prehistoric Europe: the economic basis. Methuen, London

Clark JGD (1969) World prehistory: a new synthesis. Cambridge University Press, Cambridge

Clark JGD, Piggot S (1965) Prehistoric societies. Hutchinson, London

Clarke DL (1976) Mesolithic Europe: The economic basis. In: Sieveking G, Longworth JH, Wilson KE (eds) Problems in economic and social archaeology. Duckworth, London, pp 444-481

Collins HB Jr (1937) Archaeology of St. Lawrence Island, Alaska (Smithsonian Miscellaneous Collections 96). Smithsonian Institution, Washington, DC

Conard NJ, Malina M (2016) Außergewöhnliche neue Funde aus den aurignacienzeitlichen Schichten vom Hohle Fels bei Schelklingen. Archäologische Ausgrabungen in Baden-Württemberg 2015:60-66

Conkey MW (1991) Contexts of action, contexts for power: material culture and gender in the Magdalenian. In: Gero JM, Conkey MW (eds) Engendering archaeology. Blackwell, Oxford, pp 57-92
Croes DR (1997) The North-Central cultural dichotomy on the Northwest Coast of North America: Its evolution as suggested by wetsite basketry and wooden fish-hooks. Antiquity 71:594-615

Cunningham P (2011) Caching your savings: the use of small-scale storage in European prehistory. J Anthropol Archaeol 30:135-144

Davidson I (2013) Peopling the last new worlds: the first colonization of Sahul and the Americas. Quat Int 285:1-29

Desrosiers S (2013) Textile terminologies and classifications: Some methodological and chronological aspects. In: Michel C, Nosch M-L (eds) Textile terminologies in the ancient Near East and Mediterranean from the third to the first Millennia BC. Oxbow, Oxford, pp 23-51

Drooker PB (1992) Mississippian village textiles at Wickliffe. University of Alabama Press, Tuscaloosa

Emery I (2009) The primary structures of fabrics: an illustrated classification. Thames \& Hudson, London

Evert RF, Eichhorn SE (2006) Esau's plant anatomy: meristems, cells, and tissues of the plant body: their structure, function, and development. Wiley-Interscience, Hoboken

Farbstein R, Radic D, Brajkovic D, Preston T, Miracle PT (2012) First Epigravettian ceramic figurines from Europe (Vela Spila, Croatia). PLoS ONE 7:e41437

Fischer A (1995) Man and sea in the Mesolithic: coastal settlement above and below present sea level. Oxbow, Oxford

Geib PR, Jolie EA (2008) The role of basketry in Early Holocene small-seed exploitation: implications of a ca. 9,000 year-old basket from Cowboy Cave, Utah. Am Antiqu 73:83-102

Hurcombe LM (2007) Archaeological artefacts as material culture. Routledge, London

Hurley WM (1979) Prehistoric cordage: identification of impressions of pottery (Aldine Manuals on Archeology 3). University of Toronto, Toronto

Ingold T (1983) The significance of storage in hunting societies. Man 18:553-557

Isern N, Zilhão J, Fort J, Ammerman AJ (2017) Modeling the role of voyaging in the coastal spread of the Early Neolithic in the West Mediterranean. Proc Natl Acad Sci USA 114:897-902

Jolie EA (2014) Analysis of perishables. In: Sutton M, Arkush B (eds) Archaeological laboratory methods: an introduction, 6th edn. Kendall Hunt Publishing, Dubuque, pp 123-140

Kennett JP, Kennett DJ, Culleton BJ et al (2015) Bayesian chronological analyses consistent with synchronous age of 12835-12735 Cal B.P. for Younger Dryas boundary on four continents. Proc Natl Acad Sci USA 112:E4344-E4353. https://doi.org/10.1073/ pnas. 1507146112

King ME (1978) Analytical methods and prehistoric textiles. Am Antiqu 43:89-96

Kuoni B (1981) Cestería tradicional Ibérica. Ediciones del Serbal, Barcelona

Kuzmin YV (2006) Chronology of the earliest pottery in East Asia: progress and pitfalls. Antiquity 80:362-371

Kuzmin YV, Keally CT, Jull AJT, Burr GS, Klyuev NA (2012) The earliest surviving textiles in East Asia from Chertovy Vorota Cave, Primorye Province, Russian Far East. Antiquity $86: 325-337$

Kvavadze E, Bar-Yosef O, Belfer-Cohen A, Boaretto E, Jakeli N, Matskevich Z, Meshveliani T (2009) 30,000-year-old wild flax fibers. Science (New York, NY) 325:1359. https://doi. org/10.1126/science. 1175404

Leroi-Gourhan A (1945) Evolution et techniques: l'homme et la matière. Éditions Albin Michel, Paris

Leroi-Gourhan A, Allain J (1979) Lascaux Inconnu. CNRS, Paris

Metcalfe CR (1960) Anatomy of monocotyledons, vol I. Clarendon Press, Oxford, Gramineae

Miettinen A, Sarmaja-Korjonen K, Sonninen E et al (2008) The palaeoenvironment of the 'Antrea Net Find'. Iskos 16:71-87 
Miret i Estruch C (2007) Estudi de la tecnologia lítica de la Unitat 3 de les Coves de Santa Maira -boca Oest- (Castell de Castells, Marina alta, Països Catalans). Saguntum-PLAV 39:85-102

Morales J, Mulazzani S, Belouchet L et al (2015) First preliminary evidence for basketry and nut consumption in the Capsian culture (ca. 10,000-7500 BP): archaeobotanical data from new excavations at El Mekta, Tunisia. J Anthropol Archaeol $37: 128-139$

Morales-Pérez JV (2016) Explotació dels mamífers i economía de les darreres comunitats caçadores-recol.lectores del vessant mediterrani ibèric durant la transició Tardiglacial-Holocé. Doctoral Thesis, Universitat de València, Valencia

Morales-Pérez JV, Salazar-García DC, de Miguel Ibáñez MP, Miret i Estruch C, Jordá Pardo JF, Verdasco Cebrián CC, Pérez Ripoll M, Aura Tortosa JE (2017) Funerary practices or food delicatessen? Human remains with anthropic marks from the Western Mediterranean Mesolithic. J Anthropol Archaeol 45:115-130

Nadel D, Danin A, Werker E, Schick T, Kislev ME, Stewart K (1994) 19,000-year-old twisted fibers from Ohalo II. Curr Anthropol 35:451-457

Piqué R, Romero S, Palomo A, Tarrús J, Terradas X, Bogdanovic I (2018) The production and use of cordage at the early Neolithic site of La Draga (Banyoles, Spain). Quat Int 468:262-270

Rieth CB (2004) Cordage, fabrics, and their use in the manufacture of early late Prehistoric ceramic vessels in New York. In: Drooker PB (ed) Perishable material culture in the Northeast (New York State Museum Bulletin 500). New York State Museum, Albany, pp 129-142

Romero-Brugués S, Piqué R, Picornell-Gelabert L, Calvo M, Fullola Pericot JM (2018) The production and use of cordage in the Balearic Bronze Age: the Cova des Pas (Ferreries, Menorca). Environ Archaeol. https://doi.org/10.1080/14614103.2018.15533 29

Rowley-Conwy P (1999) Economic prehistory in southern Scandinavia. In: Bewley R, Coles J, Mellars P (eds) World prehistory: studies in memory of Grahame Clark. Oxford University Press, Oxford, pp 125-129

Rowley-Conwy P, Zvelebil M (1989) Saving it for later: storage by prehistoric hunter-gatherers in Europe. In: Halstead P, O'Shea JM (eds) Bad year economics: cultural responses to risk and uncertainty. Cambridge University Press, Cambridge, pp 40-57

Rozoy J-G (1978) Les derniers chasseurs. L'Épipaléolithique en France et en Belgique. Essai de synthèse, Reims-Charleville

Schweingruber FH (1990) Anatomie europäischer Hölzer. Haupt, Bern

Soffer O, Adovasio JM, Hyland DC (2000) The "Venus" Figurines: textiles, basketry, gender and status in the Upper Paleolithic. Curr Anthropol 41:511-537

Stone EA (2011) Through the eye of the needle: Investigations on ethnographic, experimental, and archaeological bone tool use wear from perishable technologies. Doctoral Thesis, The University of New Mexico, Albuquerque

Vadillo Conesa M (2018) Sistemes de producció lítica en el trànsit Plistocè-Holocè. Estudi de la seqüència arqueológica de Coves de Santa Maira (Castell de Castells, Alacant) i la seua contextualització mediterrània. Doctoral Thesis, Universitat de València

Verdasco Cebrián CC (2016) Estudio microsedimentológico de niveles arqueosedimentarios depositados en cuevas y abrigos en el País Valenciano durante el Pleistoceno-Holoceno (11.000-5.000 BP). Doctoral Thesis, Universitat de València

Wigforss E (2014) Perished material—vanished people understanding variation in Upper Palaeolithic/Mesolithic textile technologies. Master Dissertation, Lunds Universitet, Lund

Zhushchikhovskaya IS (1997) On early pottery-making in the Russian Far East. Asian Perspect 36:159-174

Publisher's Note Springer Nature remains neutral with regard to jurisdictional claims in published maps and institutional affiliations. 